\title{
Assessing the Church of England's Leadership Response to the Covid-19 Pandemic: Listening to the Voice of Rural Lay People
}

\author{
Ursula McKenna (iD) ${ }^{1}$ \\ Email: Ursula.McKenna@bishopg.ac.uk
}

(Received 20 July 2021; revised 14 September 2021; accepted 14 September 2021; first published online 08 October 2021)

\begin{abstract}
The aim of the present study is to analyse the qualitative text written on the back page of a quantitative survey concerned with the Church of England's response to the Covid-19 pandemic. Of the 1460 rural lay people in England who took part in the Coronavirus, Church \& You survey, 501 wrote further (sometimes detailed) comments on the back page (34 per cent participation rate). This study analyses the comments made by a subsection of these 501 rural lay people, specifically the 52 participants who voiced their views on how the Church of England's leadership responded during the first four months of the Covid-19 pandemic. Analysis identified a number of issues and concerns, including: a lack of quality leadership, comparing with other Churches, becoming irrelevant, centralizing action, closing rural churches, neglecting rural people, neglecting rural clergy, marginalizing rural communities, using the kitchen table, and looking to the future. Overall, rural lay people were disappointed with the response of church leadership to the first national lockdown. If these churchgoers are to be fruitfully reconnected with their churches after the pandemic, then leadership of the Church of England may need to hear and to take seriously their concerns.
\end{abstract}

Keywords: Covid-19, Church of England leadership, quantitative surveys, qualitative data, rural lay people

\section{Introduction}

Covid-19, a highly infectious virus, was declared a pandemic by the World Health Organization on 11 March 2020. On 23 March 2020 the government in England, to control the spread of the virus, imposed a lockdown on the nation. The following day the Church of England prescribed the closure of all its churches, stating on its website:

The archbishops and bishops of the Church of England have written collectively to clergy through their dioceses, urging them now to close all church

\footnotetext{
${ }^{1}$ Dr Ursula McKenna is Senior Research Fellow at the Department of Theology, Bishop Grosseteste University, Lincoln, UK.

(c) The Author(s), 2021. Published by Cambridge University Press. This is an Open Access article, distributed under the terms of the Creative Commons Attribution licence (https://creativecommons.org/licenses/by/4.0/), which permits unrestricted re-use, distribution, and reproduction in any medium, provided the original work is properly cited.
} 
buildings - other than when they are needed to keep a food bank running, but even then under strict limits. There will be no church weddings until further notice, funerals will not take place inside church buildings and the only baptisms will be emergency baptisms in a hospital or home. ${ }^{2}$

While the churches were closed, Church of England clergy were instructed to livestream worship from their own homes. Private prayer, including by priests, was no longer permitted in church buildings (churches were subsequently allowed to open for private prayer from 13 June 2020 and for congregational worship from 4 July 2020). Across the country, in response to government advice, the policy was to close all non-essential retail, business and leisure venues, with the population instructed to stay home including, wherever possible, to work from home. As a result, in April 2020, 46.6 per cent of people in employment did some work at home and the majority of these (86 per cent) did so as a result of Covid-19. ${ }^{3}$ Likewise, during this first Spring 2020 lockdown, 24.3 per cent of businesses temporarily closed because of Covid-19 related restrictions, although the impact was felt differently across different industries, with 82.2 per cent of those associated with the arts, entertainment and recreation closing compared to 5.1 per cent of those associated with information and communication. ${ }^{4}$ The slogan was 'Stay home. Protect the NHS. Save lives.' The decision by the Church of England to close churches in March 2020 took place within this context of a major public health challenge with difficult decisions being made at great pace and certain measures being deemed as necessary. While it did so at a time when understanding of the disease was limited and frequently changing in relation to the risk factors posed to different sectors of the population, information on the transmissibility of the virus, and ways to control and contain it, the decision was not without controversy. McGowan, highlighting the problem for both clergy and lay people, suggested that:

Many worshippers, not just clergy, wanted to be connected with the spaces and places that meant much to them. Members of the Church were now being offered alternative forms of prayer and worship, via technologies not always familiar or welcome, centred on clergy whose faces had become personal avatars of worship..$^{5}$

As further surveys and reports of the impact on, and responses of, churches to the Covid-19 pandemic have been published, disquiet with the decision to close churches has grown. A report published by the Centre for the Study of Christianity and Culture (CSCC), Churches, Covid-19 and Communities: Experiences, Needs and Supporting the

\footnotetext{
${ }^{2}$ Church of England, 'Church of England to Close all Church Buildings to Help Prevent Spread of Coronavirus', https://www.churchofengland.org (accessed 3 June 2021).

${ }^{3}$ Office for National Statistics (ONS), 'Coronavirus and Working from Home in the UK', https:// www.ons.gov.uk/employmentandlabourmarket/peopleinwork/employmentandemployeetypes/bulletins/ coronavirusandhomeworkingintheuk/april2020 (accessed 3 June 2021).

${ }^{4}$ Office for National Statistics (ONS), 'Coronavirus: How People and Businesses Have Adapted to Lockdowns', https://www.ons.gov.uk/economy/economicoutputandproductivity/output/articles/coronavirushowpeople andbusinesseshaveadaptedtolockdowns/2021-03-19 (accessed 3 June 2021).

${ }^{5}$ A. McGowan, 'Communion and Pandemic', Journal of Anglican Studies 18 (2020), pp. 2-8 (3).
} 
Recovery, ${ }^{6}$ lists a range of surveys and studies carried out by Christian organizations, other faith groups and non-faith organizations in just the first 12 months of the pandemic, all expressing a number of common concerns and difficulties. ${ }^{7}$ Research carried out by CSCC, ${ }^{8}$ which included surveys at three different points in time alongside qualitative interviewing, looked at three areas related to the closure of churches: the effects on the provision of social care, the exacerbation of the impact of Covid on individual and community well-being, and the impact of closure on the experience of grief and loss. Data from over 5500 respondents (mostly over the age of 60 and from rural villages or towns) who self-identified as 'church leaders', 'church members', and 'general public' provide evidence of responses reflecting 'deep frustration and anger about closure of churches', ${ }^{9}$ with many church leaders and members expressing 'frustration at the limitations on their ability to serve communities'. ${ }^{10}$

Another survey undertaken during the first national lockdown and from which the present study draws its data, the Coronavirus, Church \& You survey, was designed to address a range of discrete but interrelated issues arising from the pandemic, from the national lockdown, and from the Church's national lock-up of churches. This survey has already been prolific in publishing its quantitative data. Studies have reported on the experiences of rural Church of England clergy and laity during the pandemic, ${ }^{11}$ including the experiences of retired clergy, ${ }^{12}$ explored attitude toward church buildings during lockdown ${ }^{13}$ and toward the sacrament of Holy Communion, ${ }^{14}$ examined the diverging responses of clergy shaped in the AngloCatholic tradition and of clergy shaped in the Evangelical tradition, ${ }^{15}$ assessed the psychological well-being of Church of England clergy and laity ${ }^{16}$ and the impact of feeling supported on the well-being of clergy through the pandemic, ${ }^{17}$ and compared the experience of Anglican churchgoers over the age of 70 with those under

\footnotetext{
${ }^{6}$ Centre for the Study of Christianity and Culture (CSCC), Churches, Covid-19 and Communities: Experiences, Needs and Supporting the Recovery (University of York: Centre for the Study of Christianity \& Culture, 2021).

${ }^{7}$ CSCC, Churches, Covid-19 and Communities, pp. 108-27.

${ }^{8} \mathrm{CSCC}$, Churches, Covid-19 and Communities.

${ }^{9} \mathrm{CSCC}$, Churches, Covid-19 and Communities, p. 14.

${ }^{10}$ CSCC, Churches, Covid-19 and Communities, p. 8.

${ }^{11}$ A. Village and L.J. Francis, 'Faith in Lockdown: Experience of Rural Church of England Clergy and Laity during the Covid-19 Pandemic', Rural Theology 18 (2020), pp. 79-86.

${ }^{12}$ L.J. Francis and A. Village. 'Viewing the Impact of Covid-19 through the Eyes of Retired Clergy', Theology 124 (2021), pp. 24-31.

${ }^{13}$ A. Village and L.J. Francis, 'Churches and Faith: Attitude towards Church Buildings during the 2020 Covid-19 Lockdown among Churchgoers in England', Ecclesial Practices (in press).

${ }^{14}$ L.J. Francis and A. Village, 'This Blessed Sacrament of Unity? Holy Communion, the Pandemic, and the Church of England', Journal of Empirical Theology (in press).

${ }^{15}$ L.J. Francis and A. Village, 'Reading the Church of England's Response to the Covid-19 Crisis: The Diverging Views of Anglo-Catholic and Evangelical clergy', Journal of Anglican Studies (in press).

${ }^{16}$ A. Village and L.J. Francis, 'Exploring Affect Balance: Psychological Wellbeing of Church of England Clergy and Laity during the Covid-19 Pandemic', Journal of Religion and Health (2021), online first.

${ }^{17}$ A. Village and L.J. Francis, 'Wellbeing and Perceptions of Receiving Support among Church of England Clergy during the 2020 Covid-19 Pandemic', Mental Health, Religion and Culture (2021), online first.
} 
age $60 .^{18}$ The impact of the pandemic on the fragile churches thesis through the eyes of clergy ${ }^{19}$ and lay people ${ }^{20}$ has also been tested, as too have differences in how male and female churchgoers experienced the Church of England's response to the pandemic. ${ }^{21}$

Both the CSCC report ${ }^{22}$ and an earlier report by Nye and Lobley ${ }^{23}$ draw attention to the perceptions of churchgoers in respect of national church leadership during the pandemic. The study by Nye and Lobley ${ }^{24}$ draws on data from 288 Christians, the majority of whom were over 55 years of age, 57.5 per cent were Anglican and half resided in villages. This study encompassed themes including: social isolation and loneliness, level of support during the crisis, volunteering, impact on feelings toward faith and community, engagement with worship, worship resources, social events, perceptions regarding local and national church responses to the crisis, and re-engaging with church and other faith-related activities. According to Nye and Lobley, while the majority of respondents felt the overall response at both local and national-levels to be at least satisfactory, 'respondents showed a greater level of satisfaction with provision of content and messages supplied at local-level than those at national-level, with a greater number believing that national-level messages and content to be poor than those supplied at local level'. ${ }^{25}$

Focusing on the role and response of Christian churches, the reports from CSCC and Nye and Lobley combine data from different Christian denominations and from different locations, including rural, urban and suburban. These data have not primarily been analysed by denomination, so differences between perceptions of Church of England or Roman Catholic responses, while highlighted, are not explored in depth. Indeed, the first questionnaire distributed (SeptemberDecember 2020) as part of the CSCC study did not ask respondents for information on faith group or denomination, although these questions were added for survey two (February-March 2021).

In drawing on quantitative data to explore the differences to emerge between the views of Anglican churchgoers aged 70 or over and the views of churchgoers under the age of 60 , one of the four main themes reported by Francis and Village ${ }^{26}$ was concerned with attitude toward the national church leadership. Francis and Village ${ }^{27}$ found that

\footnotetext{
${ }^{18}$ L.J. Francis and A. Village, 'Shielding, but Not Shielded: Comparing the Experience of the Covid-19 Lockdown for Anglican Churchgoers Aged Seventy and Over with Those Under the Age of Sixty', Rural Theology 19 (2021), pp. 31-40.

${ }^{19}$ L.J. Francis, A. Village and A. Lawson, 'Impact of Covid-19 on Fragile Churches: Is the Rural Situation Really Different?', Rural Theology 18 (2020), pp. 79-86.

${ }^{20}$ L.J. Francis, A. Village and A. Lawson, 'Impact of Covid-19 on Fragile Churches: Listening to the Voices of Lay People', Rural Theology, 19 (2021), pp. 41-47.

${ }^{21}$ L.J. Francis and A. Village, 'The Pandemic and the Feminisation of the Church? How Male and Female Churchgoers Experienced the Church of England's Response to Covid-19', Journal of Beliefs and Values (2021), online first.

${ }^{22}$ CSCC, Churches, Covid-19 and Communities.

${ }^{23} \mathrm{C}$. Nye and M. Lobley, Covid-19, Christian Faith and Wellbeing. A Report Prepared for the Arthur Rank Centre (Exeter: University of Exeter, Centre for Rural Policy Research, 2020), pp. 1-27.

${ }^{24}$ Nye and Lobley, Covid-19, Christian Faith and Wellbeing.

${ }^{25}$ Nye and Lobley, Covid-19, Christian Faith and Wellbeing, pp. 23-24.

${ }^{26}$ Francis and Village, 'Shielding, but Not Shielded'.

${ }^{27}$ Francis and Village, 'Shielding, but Not Shielded'.
} 
those aged 70 or over had less sympathy for the national leadership of the Church. Across both of the items related to this theme within the survey, the older churchgoers aged 70 or over held a less positive attitude toward the national leadership. While 42 per cent of those under 60 considered that their denomination at the national level had responded well to the crisis, the proportion fell to 36 per cent of those aged 70 or over. While 43 per cent of the younger group considered that their denomination at the national level had done a good job of leading us in prayer, the proportion fell to 36 per cent in the older group. ${ }^{28}$

\section{Research Aims}

It is against this background that the present study will draw on data collected as part of the Coronavirus, Church \& You survey ${ }^{29}$ focusing on the views and experiences of lay people either living in rural areas or worshipping in rural churches, and exploring their perceptions of national church leadership during the first four months of the Covid-19 pandemic. While existing surveys ${ }^{30}$ have highlighted national church leadership as an issue of concern, the current study will add detail to that concern by focusing more fully on identifying those aspects of national church leadership that rural lay people perceived to be most salient. It allows a more nuanced appraisal of church leadership during the pandemic, listening to and presenting the voices of rural lay people. With its focus on rural lay people, it will also add to the work of Francis et al. ${ }^{31}$ who have recently assessed the cumulative impact of the pandemic on rural Anglican churches. Building on the work of Lawson ${ }^{32}$ and the fragile rural church thesis, that local rural churches are becoming so fragile that their ongoing sustainability is being brought into question, Francis et al. ${ }^{33}$ found that both clergy and rural laity representing rural churches have a less optimistic view of the future of the rural Anglican church, post pandemic, than those in non-rural areas.

The present study seeks to add to the existing literature in two ways. First, following the previous examples of Rolph et al. ${ }^{34}$ and McKenna ${ }^{35}$ the aim was to take seriously the data entered on the back page of the survey. According to Rolph et al. ${ }^{36}$ quantitative surveys routinely dedicate the back page for participants to offer their own narrative comments, but often these comments are neither analysed nor

\footnotetext{
${ }^{28}$ Francis and Village, 'Shielding, but Not Shielded', p. 36.

${ }^{29}$ Village and Francis, 'Faith in Lockdown', pp. 79-86.

${ }^{30}$ Francis and Village, 'Shielding, but Not Shielded'; CSCC, Churches, Covid-19 and Communities; Nye and Lobley, Covid-19, Christian Faith and Wellbeing.

${ }^{31}$ L.J. Francis, A. Village and A. Lawson, 'Increasingly Fragile: Assessing the Cumulative Impact of the Pandemic on Rural Anglican Churches', Rural Theology 19.2 (in press).

${ }^{32}$ S.A. Lawson, 'Identifying Stressors among Rural Church of England Clergy with Responsibility for Three or More Churches', Rural Theology, 16 (2018), pp. 101-11.

${ }^{33}$ Francis et al., 'Increasingly Fragile'.

${ }^{34}$ J. Rolph, L.J. Francis, P. Rolph, T. ap Siôn and K. Wulff, 'Reading the Back Page: Listening to Clergy Serving in the Presbyterian Church (USA) Reflecting on Professional Burnout', Research in the Social Scientific Study of Religion 26 (2015), pp. 166-79.

${ }^{35} \mathrm{U}$. McKenna, 'Resilience in Ministry: Listening to the Voice of Church of Scotland Ministers', Rural Theology: International, Ecumenical and Interdisciplinary Perspectives (2021), online first.

${ }^{36}$ Rolph et al., 'Reading the Back Page'.
} 
reported. By analysing and reporting these narrative responses, the present study will affirm the importance of drawing on this source of original data. Second, by focusing specifically on exploring the perceptions of rural lay people with regard to leadership of the Church of England during the early months of the Covid-19 pandemic, the present study will bring these concerns into visibility. In doing so, it will add texture and richness to the quantitative findings of Francis and Village, ${ }^{37}$ CSCC $^{38}$ and Nye and Lobley ${ }^{39}$ in relation to perceptions of national church leadership and will complement existing studies focused on clergy. ${ }^{40}$

In order to achieve these two aims, the method used drew on research procedures associated with grounded theory, ${ }^{41}$ most notably in relation to analysis of the responses and the emergence and structuring of the key themes within the data. The aim was to produce analyses that captured the voice of Church of England rural lay people concerning their perspectives on how national leadership had responded to the Covid-19 pandemic, and on how this response affected their own feelings towards their faith and the wider church. Where the approach diverged from pure grounded theory was that concurrent data collection and analysis, fundamental to grounded theory research design, did not take place. Data collection and analysis did not overlap and did not inform one another. In this study analysis of the open question on the back page of the survey only began once all responses had been received. There was no further collection of data. Likewise, following the advice of Birks and Mills, ${ }^{42}$ who draw on the work of Glaser, ${ }^{43}$ formal review of the literature was delayed to prevent imposition of existing theories or knowledge on the study processes and outcomes. In this study, the decision to consult the literature was made only when all responses had been captured and analysed.

\section{Method}

\section{Procedure}

The Coronavirus, Church \& You survey was designed to assess the responses of churchgoers (clergy and laity) in the UK to the Covid-19 crisis. ${ }^{44}$ The version of the online survey shaped for distribution among Anglicans was live between 8 May and 23 July 2020, with signposting to the website distributed through both online and paper copies of the Church Times and a number of participating dioceses. Participation was voluntary, anonymous and confidential. Ethical approval was granted by the Research Ethics Committee for the School of Humanities,

\footnotetext{
${ }^{37}$ Francis and Village, 'Shielding, but Not Shielded'.

${ }^{38}$ CSCC, Churches, Covid-19 and Communities.

${ }^{39}$ Nye and Lobley, Covid-19, Christian Faith and Wellbeing.

${ }^{40}$ Francis and Village, 'Viewing the Impact of Covid-19', pp. 24-31; Francis and Village, 'Reading the Church of England's Response to the Covid-19 Crisis'; Village and Francis, 'Wellbeing and Perceptions'.

${ }^{41}$ B.G. Glaser and A.L. Strauss, The Discovery of Grounded Theory: Strategies for Qualitative Research (Chicago, IL: Aldine, 1967); B.G. Glaser, Doing Grounded Theory: Issues and Discussions (Mill Valley, CA: Sociology Press, 1998); G. Gibbs, Analysing Qualitative Data (London: Sage, 2009); M. Birks and J. Mills, Grounded Theory: A Practical Guide (London: Sage, 2nd edn, 2015).

${ }^{42}$ Birks and Mills, Grounded Theory, pp. 22-23.

${ }^{43}$ Glaser, Doing Grounded Theory.

${ }^{44}$ Village and Francis, 'Faith in Lockdown'.
} 
Religion and Philosophy at York St John University (approval code: HRP-RS-AV04-20-01). All participants had to affirm they were 18 or over and give their informed consent by clicking a box that gave access to the rest of the survey. By the time the survey was closed, over 7000 Church of England clergy and lay people had responded.

\section{Participants}

It is all too easy to be overwhelmed by the quantity and quality of the reflective comments added at the end of a survey. The aim of the present study is to concentrate on a specific segment of the available material, on the voices of lay people in England, associated with the Church of England, and either living in rural areas or worshipping in rural churches. There were 1460 participants within this category, of whom 501, comprising 148 males (30 per cent) and 353 females (70 per cent), responded to the invitation to write about their experience in their own words. In terms of age the majority of these participants were over 60 (82 per cent of males and 79 per cent of females). Within this group, 52 participants comprising 26 males and 26 females, offered their perspectives on national church leadership. Here 77 per cent of both males and females were over 60 . The largest category within the over 60 s for both those completing the back page and those writing about church leadership were participants aged 70-79 years. This is consistent with the findings of other church surveys ${ }^{45}$ that the Anglican Church is not a 'young' church in terms of its membership. The opinions presented are those of the 52 participants. No claims are made that they represent overall opinions among rural lay people more generally.

\section{Instrument}

As well as inviting participants to respond to a number of items designed for quantitative analysis, the Coronavirus, Church \& You survey closed with the following open-ended invitation.

If you would like to write about your experiences in your own words, you can do so here, or include anything that we had not asked that you think we should have included.

It is through the varied responses to this open-ended question that we are able to assess the issues that may have been most pressing on the minds of these rural lay people.

\section{Analysis}

All the online written responses were transferred to a Word document. Initial analysis involved reading through the responses several times to identify key ideas. The majority of responses were kept verbatim and decisions made on what general ideas

\footnotetext{
${ }^{45}$ Francis and Village, 'Shielding, but Not Shielded'.
} 
were being expressed by each rural lay person. Key ideas in each response were highlighted in order to identify recurrent themes. Rural lay people expressing similar themes were then grouped together. Close scrutiny of these groups revealed a number of areas related to the views and opinions of rural lay people on the impact of the first wave of the Covid-19 pandemic on the Church of England and on their experience of faith and practice. These included views on: national church leadership, local leadership and support, forms of worship, services and pastoral care, the benefits and challenges of the move to online worship and provision, fragility and survival of the church, impact on individual engagement with faith, and personal experience with the virus itself and its impact on home and working life. The category on national church leadership, the focus for the current study, was then extracted and subjected to further analysis.

Overall, the focus was on the presentation of a detailed account of what these Church of England rural lay people, when reviewed together, had to say about the response of national Church of England leadership to the Covid-19 pandemic. This was an exercise in taking seriously the issues and themes recorded by the rural lay people on the back page after they had been stimulated by and reflected on the questions posed earlier in the survey. What these comments add to the wider study is a sense of the openness and frankness with which rural lay people were willing to speak of the national Church of England leadership response to the Covid-19 pandemic and the impact of that response on their attitude toward the church and their faith during this time. It is through these narratives that the Church of England can hear the voices of rural lay people and benefit from their insights.

\section{Results}

Thematic analysis of these written responses identified 52 that referred to national leadership of the Church of England during the pandemic. What this data shows is the nature of objections among a sample of dissatisfied rural lay people. Of these 52 responses, just one was positive:

The church has I feel made a fantastic effort in rapidly providing modern worship alternatives with online services and virtual meet ups. I think on a local and national level the church response had been highly appropriate. (Female 50s)

In contrast, the majority of responses raised a number of issues and concerns. Analysis of these data identified ten themes, including: lacking quality leadership, comparing with other Churches, becoming irrelevant, centralizing action, closing rural churches, neglecting rural people, neglecting rural clergy, marginalizing rural communities, using the kitchen table, and looking to the future.

\section{Lacking Quality Leadership?}

A number of rural lay people were disappointed with what they described as the invisibility of senior church leaders. 
I just think there should have been regular national encouragement and care from the Bishops of York and Canterbury. They appear to have been very quiet in the crisis rather than leading. (Male 50s)

Embarrassing lack of leadership from the Archbishops. Unsurprising, but embarrassing, nonetheless. (Female 50s)

Nationally the Church of England has seemed to be wholly absent at a time when the voice of the Church should have been transmitted loud and clear.... From my perspective there seems to have been a wholesale failure of leadership. The previous very high regard that I had for Archbishop Welby has evaporated. Where has he been? (Male 60s)

Where leadership was evidenced, this was highlighted as being defensive rather than proactive.

The Church hierarchy has been the opposite of supportive and inspirational, instead issuing a list of rules to lock people and clergy out of our churches, defensive in their very rare articles in the press and offering no words of comfort. (Female 70s)

I feel the $\mathrm{C}$ of $\mathrm{E}$ in general ... could have been more openly proactive during this crisis. It could have been seen to feed in Christian beliefs to Government policy making. It has rather slavishly seemed to have awaited Government policy before adapting it to the routine running of the $\mathrm{C}$ of $\mathrm{E}$ churches. (Male 70s)

Some of the rural lay people who commented on the relationship between leadership of the Church of England and national government went beyond drawing attention to a mere reticence on the part of Church leadership to assert a Church or Christian input into government policy, and further accused Church leadership of an open reluctance to challenge government decision-making.

I am very disappointed with the way that the $\mathrm{C}$ of $\mathrm{E}$ has behaved as an instrument of government instead of asserting its role. From my perspective leadership of the church at all levels has largely been absent. But ... Cathedral, for example, under the leadership of the Dean has been a light in the darkness even though having to work within the cowardly restrictions imposed by the Archbishop. The opportunity should have been taken to take space within national newspapers to proclaim the good news of Jesus Christ. That this has not been done is a disgrace. The $\mathrm{C}$ of $\mathrm{E}$ does not deserve to survive and probably won't. (Male 70s)

I feel quite angry that our archbishops, our diocesan bishop and local clergy have just meekly acquiesced to churches being closed ... and aren't agitating to have them re-opened. (Female 70s)

\section{Comparing with other Churches}

Other rural lay people, critical of their own leadership within the Church of England, made comparisons with the leadership of other Christian denominations, 
and with the leadership shown by the head of the Church of England, Queen Elizabeth II. When making these comparisons, the visibility and response of the Roman Catholic Church, in particular, was frequently singled out as a contrast to the leadership actions of the Church of England which was viewed as timid and as showing a lack of courage or determination.

The Roman Catholic Church seem to have done a better job and it is interesting that media seem to have mainly been interested in what the Roman Catholic Church, or humanists, have to say, rather than the Church of England, since it has closed churches and 'retreated'. (Male 50s)

Poor response by Church of England's top leaders - Archbishops, Cathedral Deans etc to the challenge of making church space - virtual and actual - available to the laity as opposed to the response of their Roman Catholic counterparts in England and Wales. (Male 70s)

The leadership provided at the top of the $\mathrm{C}$ of $\mathrm{E}$ during the pandemic has been pusillanimous. I am giving serious thought to joining our local URC. (Male 70s)

Above all, the $\mathrm{C}$ of $\mathrm{E}$ had a golden opportunity to give prayerful leadership and was found lacking: the most inspirational, heartfelt and genuine words of spiritual comfort and belief have come from The Queen, not her churchmen. (Female 60s)

The responses here suggest that some Church of England rural lay people may give consideration to worshipping elsewhere in the future, and in doing so they give weight to the finding of Nye and Lobley, ${ }^{46}$ who maintain that due to the opening up of the virtual world churchgoers now have an increasingly available option to go elsewhere, 'Opportunities due to Covid-19 arise for inquisitive Christians to "visit" other churches or services.' For some that 'visit' may become permanent.

\section{Becoming Irrelevant}

As well as potentially losing churchgoers to other denominations, some rural lay people considered that church action, or more precisely inaction, during the pandemic would hasten the irrelevance of the church for many in society.

In the pandemic, the majority of the hierarchy of the $\mathrm{C}$ of $\mathrm{E}$ have yet again demonstrated their inability to understand the needs of humanity in pastoral as well as spiritual aspects. Closing churches ... playing with online liturgies and generally avoiding most of the social and economic issues facing humankind (now highlighted by the pandemic). It is no surprise the $\mathrm{C}$ of $\mathrm{E}$ continues to decline/become irrelevant as it retreats to its ivory towers! (Male 60s)

In the same way that the leadership given by the Queen was praised, it was stressed that the public and the nation were in fact looking to be inspired during the

\footnotetext{
${ }^{46}$ Nye and Lobley, Covid-19, Christian Faith and Wellbeing, pp. 21-22.
} 
pandemic. This was shown in responses that compared the lack of a church presence at this time with the reaction evoked by the inspiring actions of other individuals in the country.

The church, both nationally and locally, has become increasingly irrelevant during lockdown. It has failed to inspire, lead, nurture and care. Others, such as Captain Tom and Joe Wickes have captured the nation's hearts. The church has done nothing worthy of note apart from complain about lost income. (Male 50s)

\section{Centralizing Action}

One of the key complaints voiced by rural lay people was about the imposition of rules and guidance made centrally and then applied to all: 'one size does not fit all' was a statement often repeated. Not only was this centralized decision-making viewed as inappropriate, but it was also evaluated as overly cautious. Combined with this was the view expressed that national church leadership had shown a hesitancy and reluctance to act and had shown a distinct lack of trust in local decision-making.

Clergy and congregations should have been trusted to act sensibly, given their local circumstances, within the broad national guidelines, 'One size fits all' was neither necessary nor appropriate. (Male 70s)

As a church warden and regular churchgoer I did not feel that the church hierarchy gave us good spiritual support during the lockdown. Also, too many Bishops who don't appear to care for the grass roots of the Church. (Female 70s)

I am very disappointed with the leadership of the National Church, and I feel they have lacked courage, vision and faith in their incredibly slow reactions to the virus situation. At parish level we have done well, but no thanks to the diocese upwards! (Female 30s)

I have been deeply frustrated by the communications from central church (mostly nationally but also regionally) which have had a lot of 'can't do', often presented in an unhelpful way rather than allowing for each parish to make decisions based on their local practicalities and local needs. (Female 60s)

\section{Closing Rural Churches}

The impact of church closure has been identified as a key concern within many of the studies so far carried out into the impact of Covid-19. ${ }^{47}$ While the open question from the Coronavirus, Church \& You survey included many responses related to this issue, the examples cited here are taken from those that directly linked this issue to the decisions or actions of national church leadership. The closure of church buildings was viewed as sending out a negative message both to local communities and to

\footnotetext{
${ }^{47}$ Nye and Lobley, Covid-19, Christian Faith and Wellbeing; CSCC, Churches, Covid-19 and Communities; Village and Francis, 'Churches and Faith'.
} 
wider society. The message to wider society was the apparent invisibility of the Church, along with reinforcement of its non-essential status.

The Archbishops and Bishops should have spoken out that our churches are important. The Government has treated religion as part of the leisure industry on a par with pubs and restaurants. Our leaders did nothing to show that that is not true. They were too keen to demonstrate support for the government and to show that we're all in it together. (Female 50s)

I also think that the closure of churches was an over-reaction - you are no more likely to pick up an infection in church as in a supermarket, in my view. (Female 60s)

Disappointing church leaders didn't debate whether churches were an essential service, when bike shops, garages, hardware stores etc were regarded as 'essential'. (Male 70s)

I am outraged that the church authorities seem to have made no defence of the importance of worship. Popping to the shop for milk or a trip to the garden centre seem to have been deemed a higher priority than religious practice, and I have seen no evidence that the bishops disagree with that assessment. It has been disgraceful. (Male 30s)

Anglican Church overreacted by closing church buildings completely. This reinforced a sense that the church is now behaving as not much more than an extension of social care. (Male 60s)

While this view that the Church has become merely an 'extension of social care' may seem harsh, the CSCC report $^{48}$ in its executive summary would seem to confirm the sentiment expressed here. Much of the discussion about the impact of church closure in the CSCC report is framed in relation to social impacts and indeed in its introduction it states, 'For centuries, churches, alongside other faith communities, have provided what could be termed an everyday "National Wellbeing Service". 49 The Church of England website instruction of 24 March 2020 also urged church clergy to close all church buildings - 'other than when they are needed to keep a food bank running, 50

\section{Neglecting Rural People}

For local communities, the message received from the lock-up of church buildings was that the Church could not serve them, or indeed be a space for them to seek individual solace or to meet safely at a time when doing so may have been more pressing than usual. This was seen as having implications both for churchgoers and non-churchgoers living in rural areas.

\footnotetext{
${ }^{48} \mathrm{CSCC}$, Churches, Covid-19 and Communities.

${ }^{49}$ CSCC, Churches, Covid-19 and Communities, p. 7.

${ }^{50}$ Church of England, 'Church of England to Close All Church Buildings to Help Prevent Spread of Coronavirus', https://www.churchofengland.org (accessed 3 June 2021).
} 
People in rural villages who are not churchgoers often perceive the parish church as 'their' church and may well not appreciate being locked out of it, particularly when they may feel a need for private devotion or prayer. (Male 70s)

I feel let down by the Church. Church leaders have at no time shown any interest in finding ways to open churches.... There is dismay within the nonchurch going community that the focal point of our village is closed at a time when it might have attracted more interest in communal worship. (Male 70s)

I feel badly let down by the Archbishops who appear not to understand their flock or the importance of the local church building as the physical 'home' of the local church (people). Closing the church buildings also gave non-church members the signal that the church in general was 'closed for business', which confounds the error. (Male 60s)

During this lockdown we have been seriously prevented from serving the village: The church doors have been firmly locked ... we have not been permitted - even one of us - to say morning \& evening prayer in church and to chime a bell. (Female 70s)

As churchwardens many of us could have supervised a couple of hours a day in our churches or more in some cases to allow people in, to light candles and pray while cathedrals are staffed and could have continued to open for individual prayer. To be allowed to go to off licences and supermarkets but not to church has been wrong. (Female 60s)

Similar to other studies, there was a strongly held opinion among rural lay people that national church leadership was unduly hesitant in challenging government decisions, misapplied government guidance, and put up little resistance to the closure of churches. Moreover, this was not just because 'restrictions on churches increasingly came to be seen as unnecessarily risk-averse', ${ }^{51}$ but was also assessed as displaying theological illiteracy and a lack of spiritual understanding.

I am furious that the buildings have actually been locked. The shops are open so why did the $\mathrm{C}$ of $\mathrm{E}$ feel it necessary to lock churches? The Church has turned its back on the needs of those who mourn, the ill, and the dying at the very time when the Church was most needed. I have a terminal condition and am unable to go to the place where I find peace - I feel utterly abandoned. (Female 70s)

I feel so sad ... and that the Church hierarchy seemed to step back from its flock, a missed opportunity to be a Presence in a time of great need. Feel let down. (Female 60s)

Having been an active PCC member, Lay Worship assistant and Benefice Lay Chair, I have been left desolated by the response of the church in this place. It is like we have pulled up the drawbridge and run away to hide. None of this response is in any way my idea of 'what Jesus would have done'. Why do

${ }^{51}$ CSCC, Churches, Covid-19 and Communities, p. 55. 
we fear death? Don't we believe that God is in charge? The Church of England's response has been pathetic, disappointing and disingenuous. I have spent a lifetime in serving the church to now be told we must not wind the clock, ring the bells or hand deliver the Church magazine; never mind actually setting foot in the building. Furthermore, the PCC has not been consulted on any of the above decisions. (Female 60s)

As an organist, I am particularly annoyed about the closure of our church buildings .... Early on in the lockdown, the Prime Minister said that you could travel to work if you absolutely cannot work from home, which, I believe, means that if I need to use the organ to practise a piece of music I am learning for a future event, I should be allowed to do so. However, the Church of England went one step further than the Government's advice and prohibited this possibility for me. I am also subsequently disappointed that, rather than appearing to lead the Church and wider community in spirituality and prayer through Holy Week and Easter, the Archbishop of Canterbury instead chose to spend time defending these actions at what is the most important season of the Church's year. (Male 30s)

\section{Neglecting Rural Clergy}

The closure of church buildings was the decision most frequently mentioned by rural lay people as causing the most frustration and which garnered the harshest criticism from them. Not allowing priests to enter their church buildings compounded this feeling. Also contributing to their disappointment was the decision to stream church services from home, with services streamed from private homes at Easter being particularly singled out as inappropriate. Comments made in regard to these issues again reflected the feeling that the church hierarchy merely acquiesced to government decision-making rather than actively challenging those decisions.

The government gave scope for clergy to broadcast online services from inside our church buildings. The Archbishops instructed priests not to avail themselves of this. (Male 60s)

I think the Archbishops and Bishops should have at least kept the churches open for their priests. That wouldn't have caused the virus to spread. (Female 50s)

I do think that the Anglican Church has been somewhat timid in its response to the virus, where there could be some imaginative solutions to opening churches e.g. screens for relaying service sheets instead of handing out prayer books. Priests should have been allowed in their own churches at a very early stage which would have had more impact in relaying virtual services. (Male 70s)

The decision to ban priests from their own churches was simply wrong. It was understood as a firm directive and the Archbishop's attempt to finesse it later by saying that it was simply 'guidance' was unworthy. (Male 60s) 


\section{Marginalizing Rural Communities}

Linked to the issue of centralizing action and the lack of trust shown in local decision-making, there was also specific mention of the failure of national church leadership to recognize the unique circumstances of the rural church. Rural lay people felt that the rural church was being overlooked and marginalized.

I feel strongly that the national church is treating the truly rural church much the same as the government treats rural England, it doesn't understand how different we are and makes little effort to do so. (Female 80s+)

Devastated when the churches were closed for private prayer/contemplation.... Our rural church could have easily arranged for the church to be visited safely. Many people would have been glad of the chance to find some peace in churches, not just practicing Christians.... I have heard the churches have not been closed since the time of King John - what was so different now? I ask myself, what would Christ have done? Certainly not slammed the doors shut! (Female 50s)

There seems to be far too much bureaucracy at 'the top' of the $\mathrm{C}$ of $\mathrm{E}$ and little understanding of what life is like in the rural parishes! (Female 70s)

The following response was illustrative of those that combined views on the many themes so far highlighted, including the marginalisation of the rural church, church closure, and the general invisibility of the Church of England during the pandemic.

Nationally the $\mathrm{C}$ of $\mathrm{E}$ have NOT given a good lead during this pandemic. Shutting churches and themselves off from the very communities they should have been serving. There is no reason why a small rural church be treated in the same way as Winchester Cathedral. We could and should have heard our church bell ring out when 'clapping for the NHS' (no steps involved with our bell). Our church should and could have been open for quiet contemplation and prayer. A simple red/green disc on the door indicating engaged/vacant would have done! One size does not fit all and local clergy should have had more autonomy - they know what is right in their patch (helped by PCC members). Services from Clergy's homes, ok for a one off, but why not from Church thereafter? By closing everything down you have further isolated the church from the community, you should have been far more visible (national telly?). It will be very hard to re-engage now. I for one will be distancing myself from your appalling leadership and values. COMMUNITY IS KEY. (Male 60s)

\section{Using the Kitchen Table}

The decision by the Archbishop of Canterbury to live stream the Easter service for the nation from his own home, in common with the closure of church buildings, was viewed by some lay people as displaying a lack of spiritual understanding.

Why on earth did the Archbishop of Canterbury celebrate Easter in his kitchen, when there is a chapel in Lambeth Palace? Did he think he was being matey 
and 'down to earth'? No sense of spirituality. The Last Supper took place in an Upper Room, not Martha and Mary's kitchen! (Female 70s)

And as for the Easter service from Archbishop Welby's kitchen, I thought it trivialised one of the most important festivals in the church's calendar why couldn't he alone have conducted that 'service' from a church? (Female 70s)

The Church of England has also not covered itself with any glory here either hiding away in their kitchens trying to avoid any kind of blame as their major assets, their focal points around which their communities coalesce - the churches remain closed. Their priests barred from entering!!! (Male 60s)

\section{Looking to the Future}

The decisions taken by the national leadership of the Church of England has led some individuals to question their future membership of the Church.

How does one protest, and to whom, at these appalling decisions by our supposedly wise and Christian authorities. I am very seriously considering breaking all personal connection with the Church of England, which until three months ago I had loved single-mindedly through my adult life. I don't want to hear that they are merely following government guidelines.... I expect the Church authorities to reflect on the damage already done to parishioners' loyalties and to humbly follow a wiser and more sympathetic route. I'm sorry to sound uncharitable but I have little space left in my locker for archbishops or senior bishops, whose decision processes are so lamentable. Perhaps we have to recognise that all the personal efforts, work, time and money we have poured for so long into the church we love, count for nothing. Without some measure of confidence in our 'leaders' how do we sustain our loyalty? This is simply not good enough and we should be saying so at the highest level. But how? (Male 70s)

I have lost all respect for the $\mathrm{C}$ of $\mathrm{E}$ bishops and clergy over the pandemic .... I shall be reluctant to return to church as a result. (Male 70s)

My faith in Almighty God, our Creator, remains strong and firm, no thanks to the Church of England letting us down very badly, acting in an unnecessarily fearful and cautious manner - no trust in God that all will be well. In other words, when put to the test they failed. (Female 60s)

\section{Discussion and Conclusion}

Quantitative surveys routinely dedicate the back page for participants to offer their own narrative comments on the theme explored by the survey. The aim of the present study was to analyse and report the comments recorded on the back page of a survey designed for clergy and lay people serving and worshipping in the Church of England on the theme of Covid-19. The quantitative survey was completed by over 
7000 clergy and lay people of whom 501 rural lay people offered comments on the back page, which represents one third of the 1460 rural lay people in England who completed the survey ( 34 per cent). The views of these 501 rural lay people were analysed and a subsection focused on the perceptions of 52 rural lay people on church leadership at this time have been reported in this paper. Three conclusions emerge from these data analyses.

The first conclusion is that the rural lay people themselves took seriously the invitation and the opportunity offered by the back page of the quantitative survey. One third of the rural lay people (34 per cent) who participated in the survey took additional time to respond to the invitation. Moreover, a number of those who responded to the invitation offered detailed, rich, and at times emotive descriptions of their perceptions of national church leadership in its response to the Covid-19 pandemic. Such investment in the survey by the participants needs to be taken seriously by researchers.

The second conclusion is that the comments afforded rich additional insights into the theme of national church leadership among a sample of rural lay people. The themes identified by the analyses suggest that for this group of rural lay people these issues are important both for them personally and for the church. It is clear that these rural lay people were disappointed and frustrated with decisions taken at this time. In particular, they voiced concern about both the lack of any visible leadership, together with leadership that merely acquiesced to government policy as opposed to publicly challenging or asserting alternatives to that policy. The closure of churches was particularly hard to accept. This was seen as a managerial rather than a spiritual response. Closing churches, they stated, had conveyed the message that the church was non-essential and, hence, increasingly irrelevant to society. They stated that rural communities had been marginalized and rural people neglected. This had left them feeling let down by the response of national leadership. They described how a lack of spiritual support and nurture in a time of great need had challenged their membership of the Church of England, although their faith remained strong. A Church that fails to give spiritual comfort, from the perspective of these rural lay people, misses the point of Church. If not addressed, this would result in the Church losing both members and practical support in rural areas.

There is value in listening to the way in which church lay people living in rural areas or worshipping in rural churches responded to the actions of the Church and its leadership during the Covid-19 pandemic. The leadership of the Church of England may find it helpful to give serious attention to these comments from rural lay people when allocating resources for helping local churches to recover from the effects of the pandemic. These comments may also be worth keeping in mind if a resurgence of the pandemic leads to a future national lockdown. If rural lay people are alienated or feel that the Church doesn't listen to them, the Church may well lose those members. These data suggest that some churchgoers are becoming increasingly exasperated with the way in which they are being treated.

The third conclusion is that systematic attention given to the qualitative comments on the back page of quantitative surveys may be of proper benefit in shaping future research among churchgoers. The proper blend of qualitative and quantitative methods clearly enriches the science of congregation studies. 
There are four main weaknesses to this study. First, the views and opinions reported here come from data collected during the first national lockdown in Spring 2020. It is possible that views on, and perceptions of, leadership might have changed with subsequent lockdowns. As the CSCC report ${ }^{52}$ helpfully outlines, as months passed there was a gradual change in Church of England national policy alongside a move towards making the decision to close churches a local one. However, while senior clergy and archbishops did in these later months lobby the government and advocate for churches to be allowed to remain open, both for public worship and private prayer, they still proceeded with hesitancy, perhaps maintaining an unduly over-cautious approach. Thus, in December 2020 they advised that for Christmas 2020 'Even though attending public worship is permitted, many people may feel it is currently better they do not do so. Clergy and others who are shielding should certainly feel no compulsion. ${ }^{53}$ Hence, while stating churches could open and priests were permitted to enter buildings, church guidance also allowed churches and priests to exempt themselves from doing so.

Second, positive statements in relation to views on national church leadership during the first four months of the Covid-19 pandemic were few. The data reported here is limited to those who completed the back page. Those completing this section may have leaned towards those who wanted anonymously to raise concerns and frustrations. The uncertainty across the whole country during the early months of the Covid-19 pandemic was unsettling for many. Those rural lay people in a more positive personal space may have been less inclined to complete this section. Hence, there is a need to correlate these data with the responses from the overall survey.

Third, responses have not been analysed in terms of gender or age. There might be value in exploring whether different factors are at work for male and female rural lay people or between younger and older rural lay people, as evidenced in the quantitative analyses reported by Francis and Village ${ }^{54}$ on age differences and by Francis and Village ${ }^{55}$ on sex differences, also drawing on data from the Coronavirus, Church \& You survey. Detailed content analysis of the qualitative data generated by the survey showed that the key themes presented by men and by women were largely identical. The only difference was that for lay rural females an additional (and significant) category was discernible. Here, female respondents were reflecting on either personal challenges (job pressures, caring responsibilities, uncertainty, illness, isolation and loneliness, vulnerability) or personal benefits (positive and liberating, slower pace, time for reflection and exercise, family focus, study opportunities) experienced during the Covid-19 lockdown. Working from home, and the increasing use of the virtual world were viewed equally by some females as a benefit but by others as a challenge. This category of very personal response was absent in the lay rural male responses.

Fourth, as was also acknowledged in the study by Nye and Lobley, ${ }^{56}$ this survey was biased towards those who were computer literate and it is possible that

\footnotetext{
${ }^{52}$ CSCC, Churches, Covid-19 and Communities, pp. 128-31.

${ }^{53} \mathrm{CSCC}$, Churches, Covid-19 and Communities, p. 130.

${ }^{54}$ Francis and Village, 'Shielding, but Not Shielded'.

${ }^{55}$ Francis and Village, 'The Pandemic and the Feminisation of the Church?'.

${ }^{56}$ Nye and Lobley, Covid-19, Christian Faith and Wellbeing, p. 16.
} 
responses belonging to individuals who are less computer literate might be different to those collated here. Nonetheless, the implications of this study are important for the Church of England in taking seriously the views of its rural lay people and in reflecting on its own leadership practices.

Cite this article: McKenna, U. (2023). Assessing the Church of England's Leadership Response to the Covid-19 Pandemic: Listening to the Voice of Rural Lay People. Journal of Anglican Studies 21, 34-52. https://doi.org/10.1017/S1740355321000401 